\section{Shiva Pradeep N}

Student

BMS College of Engineering, Bangalore Department of Mechanical Engineering

\section{Padmakumar M}

Lead Engineer Kennametal India Limited

Technology Centre
India

B N Sarada

Assistant Professor BMS College of Engineering, Bangalore Department of Mechanical Engineering
Experimental Investigation to Assess the Effects of Trumpet Hone on Tool Life and Surface Quality in Milling of AISI4140 Steel

Cutting edge preparation is proven to improve the tool life by avoiding sudden failures. Honed edge is effective in stabilizing the tool but has an adverse effect on surface quality. Tailored edge draws attention for research in improving the tool life and surface quality compared to symmetric honed edge. This research describes the advantages and limitations of trumpet edges over symmetrically honed edges in tool life and surface quality. The analysis carried out in milling of AISI 4140 steel with the trumpet edge of $K=1.6$ produced a surface of stable Ra value around $0.2 \mu \mathrm{m}$ with good quality. The tool life was not significantly varied with the trumpet edges since the both trumpet edge and symmetrical edges resulted in a tool life around 95 minutes. The results predict a distortion of tailored edge as it machines the work piece since the K-factor was reduced from 1.6 to 0.9 .

Keywords: Cutting tool, Edge preparation, Edge hone, Tool life, Surface roughness, K-factor.

\section{INTRODUCTION}

Tool geometry is found to be a key to developing the cutting tools with optimum performance. It is seen that tool macro geometry controls the cutting forces and tool life. Tools are further optimized in design by adopting variety of tool micro-geometries. The micro-geometry refers to the edge preparation which is imparted into the tools in order to prevent early tool breakages. Edge preparation can either be chamfered or honed. The honed edges produce additional passive forces known as ploughing forces compared to sharp edges in which the ploughing is insignificant [1]. The corner radius in combination with the smaller edge radius improves the tool life minimizing wear, whereas larger hone radius increases the forces [2]. The variation in feed has larger effect on forces in chamfered edge compared to honed edge. The honed edge produces lesser forces compared to chamfered edges [3].The edge honing was proven to be necessary to increase the stability of the tool by ensuring the edge to be more resistant to wear and avoiding stress concentration before coating [4].

The edge preparation can be done in different ways and three major types of edge hone profiles can be generated. Edge hone profile is judged by an important parameter known as form factor or K-factor. The term $\mathrm{K}$-factor is geometrically described as follows:

The value of K-factor determines whether the edge radius is more inclined towards rake or flank. $\mathrm{K}$-factor was found to vary the tool performance and making a

Received: August 2018, Accepted: January 2019

Correspondence to: Padmakumar M, Lead

Engineer, Kennametal India Limited Technology

Centre, India

E-mail: mpadmakumar86@gmail.com

doi: $10.5937 /$ fmet1903437S

(C) Faculty of Mechanical Engineering, Belgrade. All rights reserved difference in the obtained tool life. The heat transfer and temperature developed were found to depend on form factor. It also had an impact on the stress developed at the tool tip causing variations in tool wear and surface finish [5]. The $\mathrm{S} \alpha$ had significant impact on the temperature profile near the edge rather than $S \gamma$ and hence it has larger influence on tool life and wear rate [6]. The higher $\mathrm{S} \alpha$ was found to generate more friction between the work piece and flank and consequently increases the wear rate. Hence trumpet edge $(K>1)$ resulted in a better tool life due to lower $\mathrm{S} \alpha$ values when compared to waterfall and symmetric edges [7]. The occurrence of ploughing was observed to be higher at larger $\mathrm{S} \alpha$ and hence it resulted in a lower tool life [8]. It is evident from the background study that the asymmetrical edge hone has an impact on tool life and surface quality. But it has to be ensured that the extreme care is taken while measuring the edge profile since incorrect measuring methods will lead to a false characterization $[9,10]$. A decrease in form factor with larger contact length along flank face resulted in a increase in tool load as well as tool wear $[11,12]$. The contradictory results were obtained by an experimental work carried out by Fulemov et al,[13] 2015 in which lower K-factor generated better quality surface and improved tool life. This was explained as the insert adopted had wiper geometry and caused a different performance.

The use of larger honed edges was found to negatively affect the finished surface quality. Edge honing is done by different technologies like immerse tumbling, magnet brushing, drag finishing, grinding and abrasive brushing [14]. The chamfered edges control the rake angles and edge preparation helps in avoiding stress concentrations which weakens the edge [15]. Asymmetrical edge with lower $\mathrm{S} \alpha$ eliminated the material side flow and improved surface quality [16]. Prediction of forces in 
machining is important in determining power, dimensional accuracy, form, surface finish and fixtures [17].

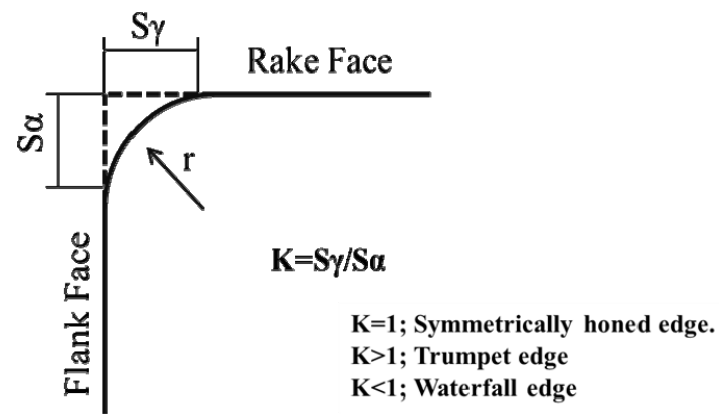

Figure 1. Geometrical representation of honed edge parameters.

The present research investigates the influence of trumpet honed edges over symmetric edge on tool life and surface quality in milling of AISI4140.

\section{MATERIALS AND METHODS:}

The performance of the tool in milling of AISI4140 steel is studied in this research. The tool life is an important criterion that predicts the economic justification of the tool. The surface quality plays a critical role in many applications. Hence the tool life and surface roughness are monitored in this research using PVD coated milling inserts of different edge micro-geometries. The following chart explains the processes adopted in this study.

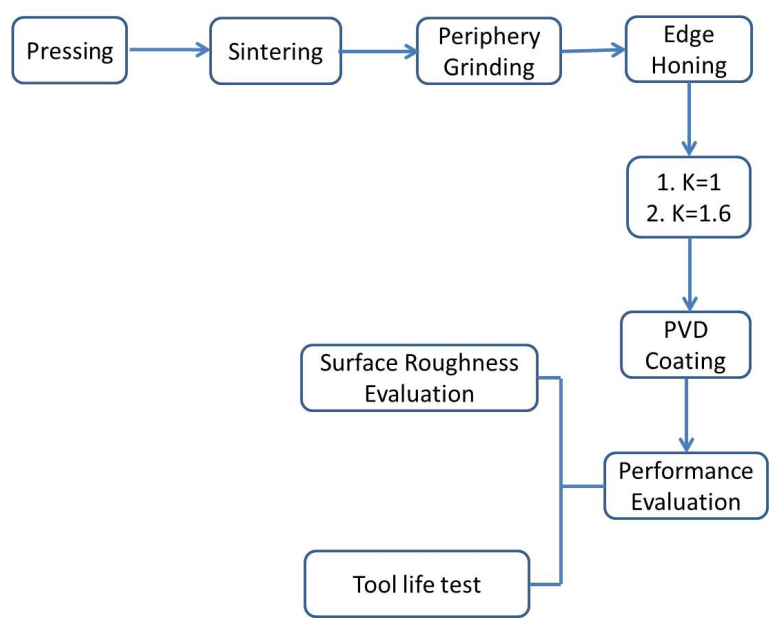

Figure 2: Representation of steps carried out in the research

Inserts were pressed and sintered to size. The edge honing was carried out with controlled set up to achieve two types of micro geometries with $\mathrm{K}=1$ and $\mathrm{K}=1.6$. PVD coating of thickness $3 \mu \mathrm{m}$ was applied on the honed inserts uniformly. The scratch and adhesion tests were carried out on the coating as per ISO 1071-3. Performance of inserts is evaluated by tool life and quality of the surface produced.
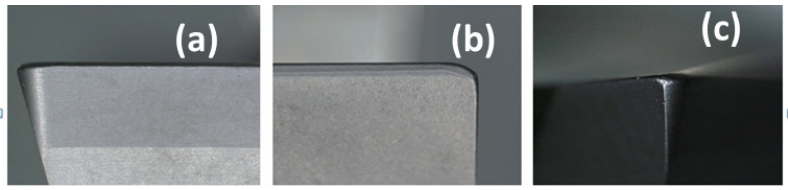

Figure 3: (a) Flank (b) Rake (c) Nose of the insert with $\mathrm{K}=1.0$

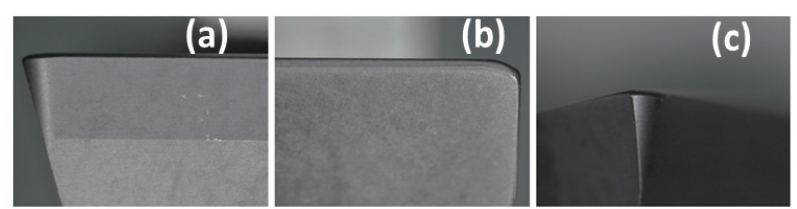

Figure 4: (a) Flank (b) Rake (c) Nose of the insert with K=1.6

The edge conditions of the coated inserts were inspected and the details are listed below:

Table 1: Edge Conditions of the inserts

\begin{tabular}{|c|c|c|c|}
\hline Insert No & K factor & $\mathrm{S} \alpha(\mu \mathrm{m})$ & $\mathrm{S} \gamma(\mu \mathrm{m})$ \\
\hline 1 & 1.0 & 55 & 55 \\
\hline 2 & 1.6 & 28 & 45 \\
\hline
\end{tabular}

The work piece AISI 4140 was annealed at $872^{\circ} \mathrm{C}$ and subjected to slow cooling in the furnace. The experiment was conducted in a vertical CNC milling machine as per the below conditions mentioned in table 2 and tool life was evaluated by measuring the flank wear for every $1500 \mathrm{~mm}$ of machining length. A maximum flank wear criterion is set to $0.3 \mathrm{~mm}$ as per ISO 8688 1:1989 standard. The surface roughness was measured by varying the feed rate from 0.1 to $0.35 \mathrm{~mm} / \mathrm{rev}$.

Table 2: Machining Conditions for the experiment

\begin{tabular}{|c|c|}
\hline Machining Conditions & Parameters \\
\hline Insert Type & XPHT160408 \\
\hline Coating Type & PVD \\
\hline Cutting Speed & $175 \mathrm{~m} / \mathrm{min}$ \\
\hline Cutter Diameter & $50 \mathrm{~mm}$ \\
\hline No of Teeth & 5 \\
\hline Lead angle & 0 \\
\hline Axial Depth of Cut & $2 \mathrm{~mm}$ \\
\hline Radial Engagement & $30 \mathrm{~mm}$ \\
\hline Feed rate/teeth & $0.2 \mathrm{~mm}$ \\
\hline Material & AISI4140 \\
\hline Hardness & 230 BHN \\
\hline
\end{tabular}

\section{RESULTS AND DISCUSSIONS:}

\subsection{Study on influence of trumpet edge on surface roughness:}

The results of surface roughness evaluation show the comparison between the qualities of surface produced by symmetric $(\mathrm{K}=1)$ and trumpet edge $(\mathrm{K}=1.6)$. The result is shown in the figure 5 and figure 6.

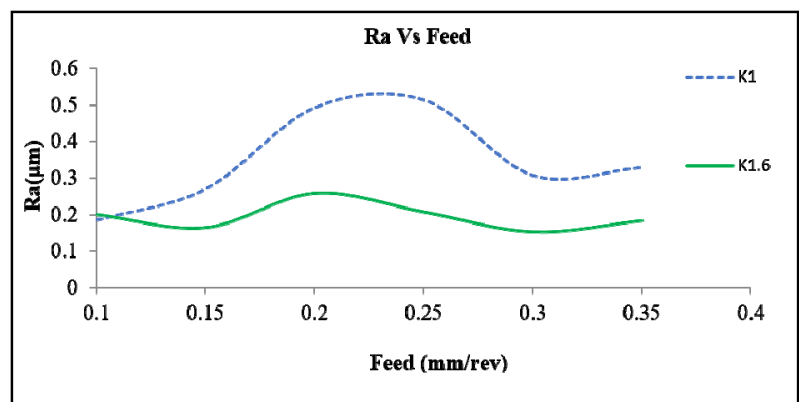

Figure 5: Graph of Ra Vs Feed rate for different edges

The results infer that the surface quality is improved by adopting cutting tools with higher K-factor. Even though the improvement is not much significant, larger variations in Ra values are observed in symmetric edge 
when compared with the trumpet edge. The insert with $\mathrm{K}=1.6$ is found to produce the surface with lower and stable Ra values along different feed values. This can be substantiated by the lower values of $\mathrm{S} \alpha$ and hence lower contact of the flank with the work-piece which results in a lesser friction. The cutting edge conditions were measured after the experiment and the results are given in the table 3 .

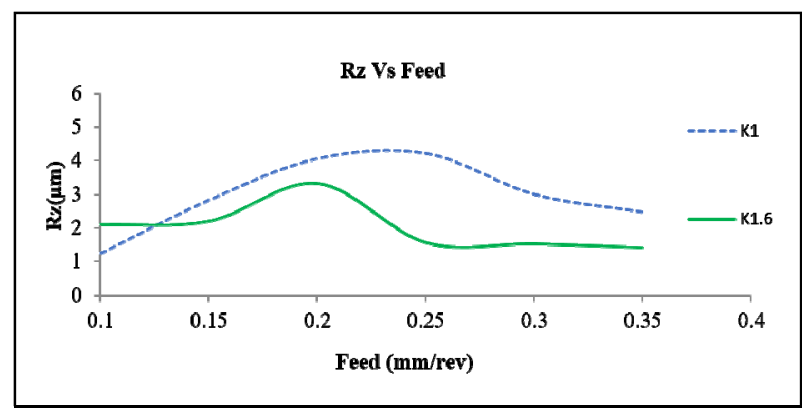

Figure 6: Graph of Rz Vs Feed rate for different edges

Table 3: Edge Conditions of the inserts

\begin{tabular}{|c|c|c|}
\hline $\begin{array}{c}\text { Insert } \\
\text { No }\end{array}$ & $\begin{array}{c}\text { K factor before } \\
\text { Machining }\end{array}$ & $\begin{array}{c}\text { K factor after } \\
\text { machining }\end{array}$ \\
\hline 1 & 1.0 & 0.80 \\
\hline 2 & 1.6 & 0.90 \\
\hline
\end{tabular}

It is observed that the cutting edge did not retain its $\mathrm{K}$-factor after machining. Hence SEM image of the cutting-edge is taken and result is shown in figure 7.
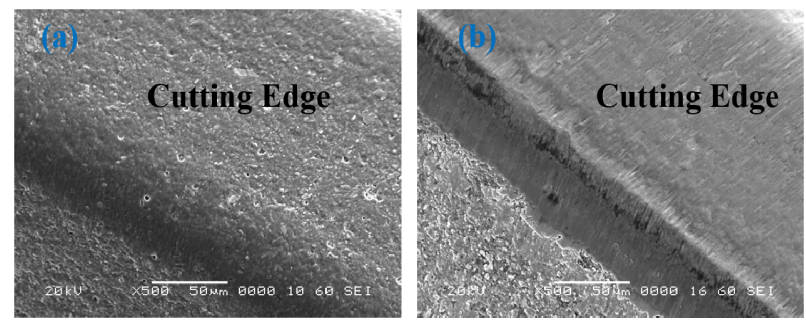

Figure 7: SEM image of cutting edge with $\mathrm{K}=1.6$ (a) before and (b) after machining.

From the SEM image, changes in the cutting edge are observed in the machined region which may be due to adhering of different material layer on the edge or due to the coating layer worn out. The SEM images taken show a clear change in the edge micro-geometry after machining. The edge surface has the irregularities which might have changed the edge micro-geometry after machining. A detail study on this will be carried out in the future work.

\subsection{Study on influence of trumpet edge on tool life:}

Tool life is compared between the symmetric edge and trumpet edge. In general conditions flank is subjected to more abrasion due to friction with the work piece and hence flank wear progression is monitored in this study. The comparison of wear progression between both the edges is shown in figure 8 .

Even though trumpet hone was found to wear at a slower rate compared to symmetric edge, it has failed around the same time as symmetric edge. The initial lower wear observed is due to the lower friction developed between the flank and work piece as it had lower values of $\mathrm{S} \alpha$. But at the later stage this difference is nullified as the machining proceeds. The trumpet edge was expected (Denkenna et al, 2012) to give better tool life but it has failed at around 94 minutes. The symmetric edge reached the maximum wear at around 99 minutes which shows that edge preparation does not have a significant impact on the tool life. But from the study, it may be inferred that there may be some distortions in edge hone profile which reduces the performance as machining proceeds.

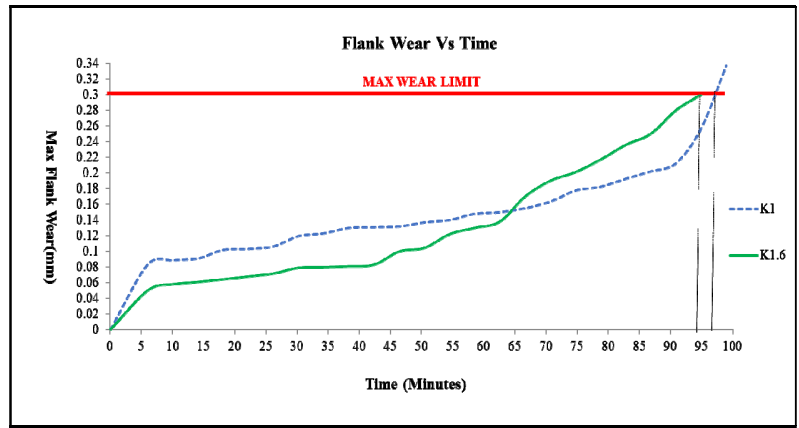

Figure 8: Graph representing tool life for different edges

Table 4: Tool life results for both the edges

\begin{tabular}{|c|c|}
\hline Insert Type & Tool life(Minutes) \\
\hline$(\mathrm{K}=1.0)$ & 99 \\
\hline$(\mathrm{K}=1.6)$ & 95 \\
\hline
\end{tabular}

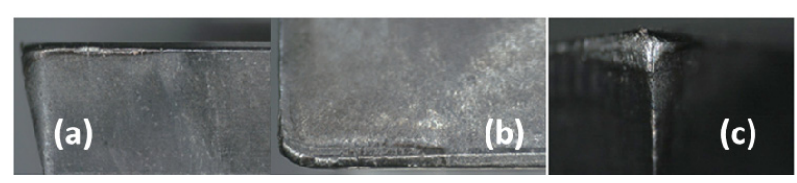

Figure 9: Wear photos of (a) Flank (b) Rake (c) Nose of the insert with $\mathrm{K}=1.0$

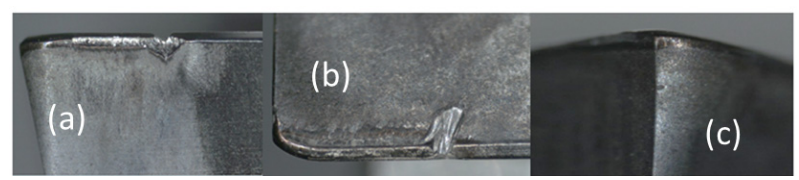

Figure 10: Wear photos of (a) Flank (b) Rake (c) Nose of the insert with $\mathrm{K}=1.6$

The cutting edge with $\mathrm{K}=1.6$ is subjected to more crater wear when compared to cutting edge with $\mathrm{K}=1.0$. This is justified with the higher values of $\mathrm{S} \gamma$ in the case of trumpet edge. From the study, it is also observed that flank wear was more in the case of symmetric edge for initial 60 minutes of machining due to higher contact length along flank face.

\section{CONCLUSION}

The edge-honing is effective in improving tool wear resistance and the performance of trumpet is evaluated in terms of tool life and surface roughness with symmetric edge in milling of AISI4140 steel. Following conclusions can be drawn from this research activity:

- Trumpet honed edge was found to produce the surface with lower and constant $\mathrm{Ra}$ values compared to symmetric edge.

- The higher value of $\mathrm{S} \alpha$ along the flank face in symmetric edge is responsible for the variations in Ra value. 
- Even though the initial tool wear was lower in the case of trumpet edge, it did not result in any improvement in tool life.

- The lower value of $S \alpha$ reduced the initial flank wear while machining with trumpet edge.

- The further work can be performed to evaluate the effects of trumpet edge on forces, chip formation, temperature developed in the cutting zone and microstructure changes on the machined surface.

- The deterioration in the performance of trumpet edge may be due to the change in Kfactor of the trumpet edge and has to be studied in the future work.

\section{ACKNOWLEDGMENT}

The authors would like to acknowledge Kennametal India Limited for the assistance in conducting the experiments.

\section{REFERENCES}

[1] Albrecht, P.: (1960) New developments in the theory of metal cutting process, Journal of Engineering for Industry, Vol 82, No.4, pp 348358.

[2] Endres, W. J. Kountanya, R.K., (2002) The Effects of Corner Radius and Edge Radius on Tool Flank Wear, Journal of Manufacturing Processes, Vol.4, No.2, pp 89-96.

[3] Fang, N. Wu, Q.: (2005) The effects of chamfered and honed tool edge geometry in machining of three aluminium alloys, International Journal of Machine Tools and Manufacturing, Vol. $45 \mathrm{pp}$ 1178-1187.

[4] Recha, J. Yen, Y.C., Schaff, M.J. , Hamdia, H., Altan, T., Bouzakis, K.D.: (2005) Influence of cutting edge radius on the wear resistance of PMHSS milling inserts, Wear, Vol. 259, pp. 11681176

[5] Karpat, Y. O“zel, T.: (2008), Mechanics of high speed cutting with curvilinear edge tools, International Journal of Machine Tools and Manufacturing, Vol 48, pp 195-208.

[6] Denkena, B. Lucas, A., Bassett, E.: (2011) Effects of the cutting edge microgeometry on tool wear and its thermomechanical load, CIRP Annals Manufacturing Technology, Volume 60, pp. $73-$ 76.

[7] Bassett, E. Kohler, J.,Denkena, B. (2012) On the Honed Cutting Edge and its Side Effects During Orthogonal Turning Operations of AISI1045 with Coated WC-Co Inserts, CIRP Journal of Manufacturing Science and Technology, Vol. 5, pp 108-126.

[8] Denkena, B. Koehler, J., Rehe, M.: (2012) Influence of the Honed Cutting Edge on Tool Wear and Surface Integrity in Slot Milling of $42 \mathrm{CrMo} 4$ Steel, Procedia CIRP, Vol. 1, pp. 190 - 195.

[9] Wyen, C.F. Knapp, W., Wegener K., (2012) A new method for the characterization of rounded cutting edges, International Journal of Advanced Manufacturing Technology, Vol 59, pp 899-914.

[10] Yussefian, N.Z. Koshy, P., (2013) Parametric characterization of the geometry of honed cutting edges, Precision Engineering, Vol. 37, pp. 746752.

[11]Denkena, B. Biermann, D.: (2014) Cutting edge geometries, CIRP Annals Manufacturing Technology, Vol 63, No.2, pp 631-653.

[12] Ventura, C.E.H. Köhler, J., Denkena B., (2015) Influence of cutting edge geometry on tool wear performance in interrupted hard turning, Journal of Manufacturing Process, Vol.19, pp 129-134.

[13] Fulemov, J. Řehoř, J., (2015) Influence of form Factor of the Cutting Edge on Tool Life during Finishing Milling, Procedia Engineering, Vol 100, pp $682-688$.

[14] Uhlmanna E. Oberschmidt, D., Kuche, Y., Löwenstein, A.,Winker, I., (2016) Effects of different cutting edge preparation methods on micro milling performance, Procedia CIRP, Vol. 46, pp 352-355.

[15] Cheng, X. Jin, S., Liao, T., Jiang, F., (2017) Optimizing the geometric parameters of chamfered edge for rough machining $\mathrm{Fe}-\mathrm{Cr}-\mathrm{Ni}$ stainless steel, International Journal of Advanced Manufacturing Technology, Vol. 91, No. 4, pp 137-146.

[16] Maiss, O. Grove, T., Denkena B.: (2017) Influence of asymmetric cutting edge roundings on surface topography, Production Engineering Research and Development, Vol. 11, No.4-5, pp 383-388.

[17] Popovic, M. Tanovic, L. Ehmann, K.F.: (2017) Cutting forces prediction: The experimental identification of orthogonal cutting coefficients. FME Transactions, Vol. 45, pp 459-467.

\section{ЕКСПЕРИМЕНТАЛНО ИСТРАЖИВАЊЕ У ЦИЉУ ПРОЦЕНЕ УТИЦАЈА ХОНОВАНОГ КОНИЧНОГ РЕЗНОГ СЕЧИВА НА ПОСТОЈА- НОСТ АЛАТА И КВАЛИТЕТ ЗАВРШНЕ ОБРАДЕ КОД ОБРАДЕ ГЛОДАЊЕМ ЧЕЛИКА AISI4140}

\section{С. Прадеп Н, Падмакумар М, Б.Н. Сарада}

Доказано је да припрема резног сечива побољшава постојаност алата јер се тиме избегава изненадни отказ алата. Хоновано сечиво је ефикасно за стабилизовање постојаности алата али има неповољан утицај на квалитет завршне обраде. Прилагодљиво конично сечиво све више постаје предмет истраживања у циљу побољшања постојаности алата и квалитета завршне обраде у поређењу са симетрично хонованим сечивом. У раду се наводе предности и ограничења коничних сечива у односу на симетрично хонована сечива код постојаности алата и квалитета завршне обраде. Анализом процеса обраде глодањем челика AISI 4140 са коничним сечивом са фактором $\mathrm{K}=1,6$ добијена је површина стабилне вредности са Ra приближно 0,2 $\mu \mathrm{m}$ добре завршне 
обраде. Постојаност алата није значајно варирала код коничног сечива пошто су оба типа хонованих сечива остварила постојаност алата од приближно
95 мин. Резултати предвиђају искривљење прилагођеног сечива при обради обратка, јер је К фактор редукован са 1,6 на 0,9 . 